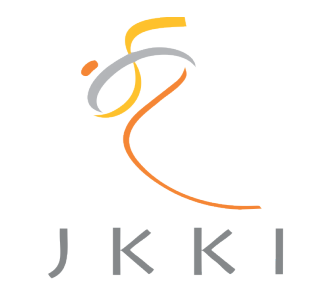

SCIEMTIR EST BASIC VITAE

\section{Jurnal Kedokteran dan Kesehatan Indonesia}

\author{
Indonesian Journal of Medicine and Health
}

Journal homepage: www.journal.uii.ac.id/index.php/jkki

\title{
Solid waste management at the RS Jogja and RS PKU Muhammadiyah in jogja
}

Muchsin Maulana*1,Hari Kusnanto ${ }^{2}$, Agus Suwarni ${ }^{3}$

${ }^{1}$ Faculty of Public Health, University of Ahmad Dahlan

${ }^{2}$ Field Epidemiology Training Program, Gadjah Mada University

${ }^{3}$ Health Polytechnic, Health Ministries

Original Article

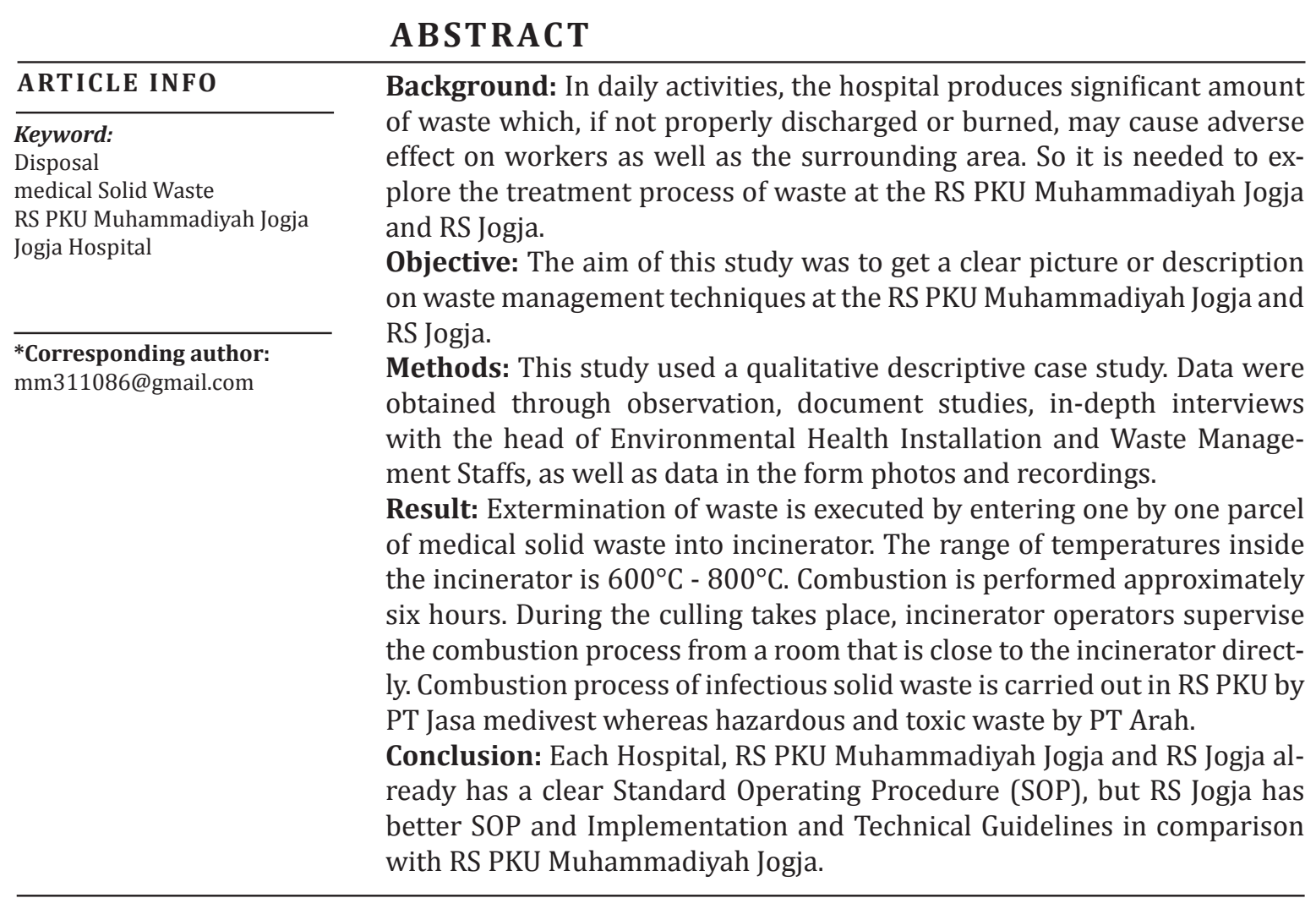

Latar Belakang: Rumah Sakit Jogja dalam kegiatan seharinya menghasilkan limbah yang dapat menimbulkan efek buruk pada petugas maupun daerah sekitar. Rumah Sakit Jogja memiliki insinerator, sehingga mempermudah dalam pengelolaan limbah Rumah Sakit. Pengelolaan limbah, perlu diekplorasi untuk mengetahui bagaimana proses pengelolaan limbah padat di RS PKU Muhamadiyah Kota Jogja dan Rumah Sakit Jogja.

Tujuan: Penelitian ini bertujuan untuk membuat gambaran atau deskripsi tentang suatu keadaan secara objektif.

Metode: Penelitian ini menggunakan rancangan studi kasus deskriptif kualitatif. Unit analisis adalah pengelolaan limbah padat di Rumah Sakit Jogja dan RS PKU Kota Jogja. Sumber data didapat dari observasi, wawancara mendalam kepada Kepala Instalasi Kesehatan Lingkungan dan Petugas Pengelolaan Limbah 
dan studi dokumen serta data berupa hasil foto dan rekaman.

Hasil: Proses selanjutnya dilakukan pemusnahan dengan cara memasukkan satu persatu bungkusan limbah padat medis. Pemusnahan dilakukan dengan pembakaran melalui insinerator dengan suhu berkisar $600^{\circ} \mathrm{C}-800^{\circ} \mathrm{C}$ yang dilakukan oleh operator insinerator. Pembakaran dilakukan kurang lebih enam jam. Selama pemusnahan berlangsung, operator Insinerator mengawasi proses pembakaran dengan berada di ruang yang bersampingan langsung dengan Insinerator. Proses pembakaran limbah padat Infeksius di lakukan di RS PKU Kota Jogja oleh pihak ke-tiga PT Jasa medivest sedangkan limbah bahan berbahaya dan beracun oleh PT Arah.

Kesimpulan: Masing-masing Rumah Sakit, RS Jogja dan RS PKU Kota sudah mempunyai Standart Operating Procedure (SOP) yang jelas, namun hasil yang didapatkan bahwa RS Jogja mempunyai SOP serta Petunjuk Pelaksana dan Petunjuk Teknis yang lebih jelas.

\section{INTRODUCTION}

Hospital, a gathering place and health-care facilitator for the sick and healthy people, can be a place of disease transmission and creating the environmental pollution and health problems. ${ }^{1}$ Hospital environmental management is now no longer a part of consumptive section, but it is a series of cycles and hospital management strategies to develop environmental management capacity in the hospital that provides benefits directly or indirectly to the improvement of overall service quality in hospital. Environmental management of hospital has complex problems. One of the key problems of hospital is waste, which is highly sensitive to government regulation. Hospital as one of the biggest waste producers has the potential to cause pollution to the surrounding environment that would be harmful for society even for Hospitals itself. ${ }^{2}$

Different group of people are at risk of health problems due to pile of hospital garbage. First, patients who come to the hospital to take medical assistance and hospitality. This group is the most vulnerable groups. Second, the employee of hospital who carry out their daily tasks always in contact with a sick person who is the source of disease agents. Third, the visitors who visit the hospital to see the sick people. The risk of associated health problems will be even greater for them. Fourth, people who live around the hospital, especially if the hospital does not have the proper disposal system of waste products. Besides, if the environmental quality is down, then it will affect the public health substantially. Therefore, it is required to implement the waste management system in hospital perfectly. ${ }^{3}$

According to Bondan Agus Suryanto (KaDinKesProp. DIY) around 64 percent of among the 14 specialized hospitals (RS) in DIY do not manage waste properly and safely. Only 36 percent of specialized hospitals in the province manage waste properly and safely. The number of general hospitals in this province are 16, which manage waste properly and safely are about 50 percent, while those not qualified waste management are also 50 percent. Major hospitals in DIY such as RS Sardjito, Panti Rapih, Bethesda, and the RSUD Wirosaban Hospital do not fulfill the criteria of appropriate waste management. ${ }^{4}$

Hospital Wirosaban or Jogja Hospital is a Government Hospital which perform the processing of waste properly, so it needs to be explored to find out how to use the facilities provided by the City Government of Yogyakarta and the process of waste management at the Hospital of Yogyakarta or Government Hospital as well as its comparison with the private hospital such as RS PKU Muhammadiyah in Jogja.

\section{METHODS}

The research was a qualitative descriptive research having the main objective to create a real picture or a description of waste management situation. ${ }^{5}$ The unit of analysis in this study was the processing of solid waste management in RS Jogja and RS PKU Muhammadiyah in Jogja. The sources of collecting information were head of Environmental Health Installation, head of sub-section, environmental affairs officer, waste management officer as well as documents and reports related to solid waste 
at RS PKU Muhammadiyah in Jogjakarta and RS Jogja.

\section{RESULTS}

1) Solid waste treatment at the RS Jogja: The processing of solid waste conducted by the Hospital Jogja is shown in Figure 1.

It refers to the Decree of the Minister of Health of the Republic of Indonesia Number 1204/Menkes/SK/X/2004 on environmental health requirements in hospital, which was adjusted at the field condition of the RS Jogja. i. Processing of medical solid waste

Figure 1 below shows the process of solid waste processing in RS Jogja.

ii. Processing of non-medical solid waste Steps of non-medical solid waste processing by WMSs at the Jogja hospital shown in figure2.

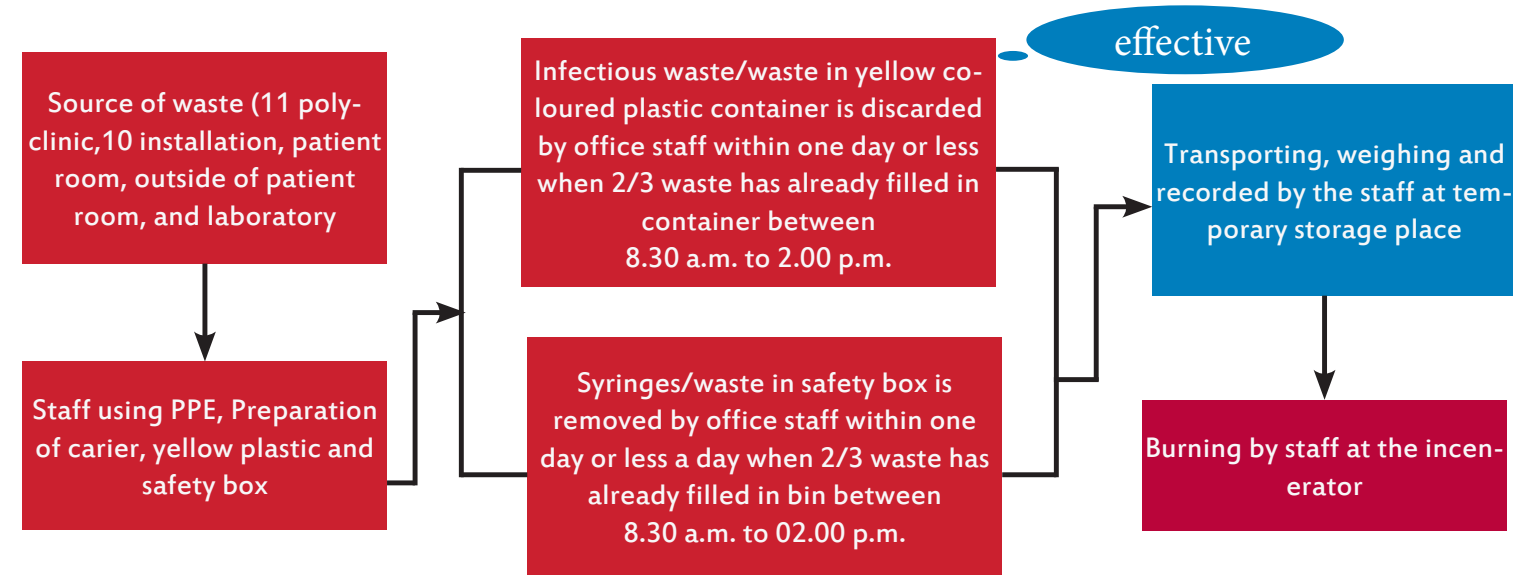

Figure 1 Proces of medical derived solid waste management undertaken by the waste management staff at the RS Jogja

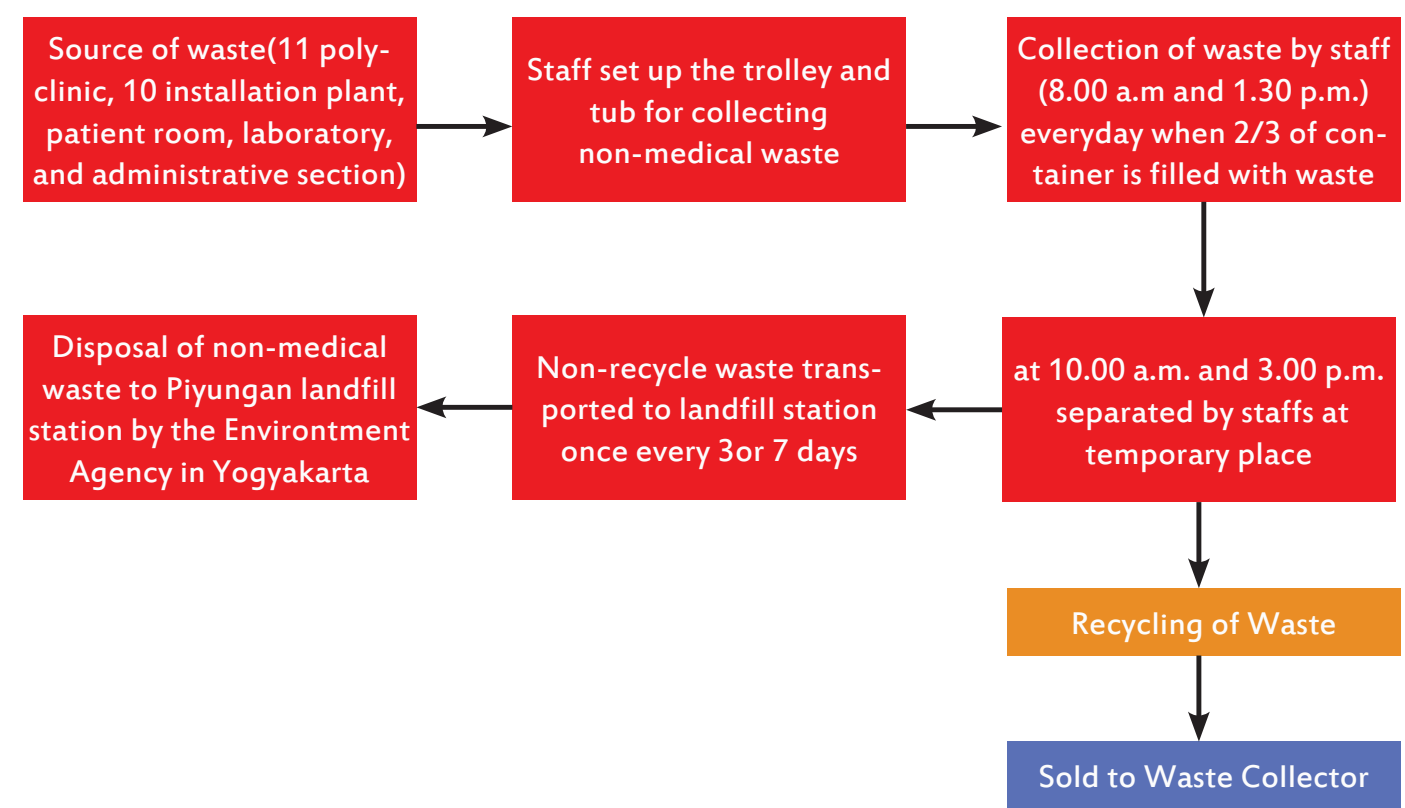

Figure 2 Non-medical solid waste treatment process by WMS conducted at the RS Jogja. 


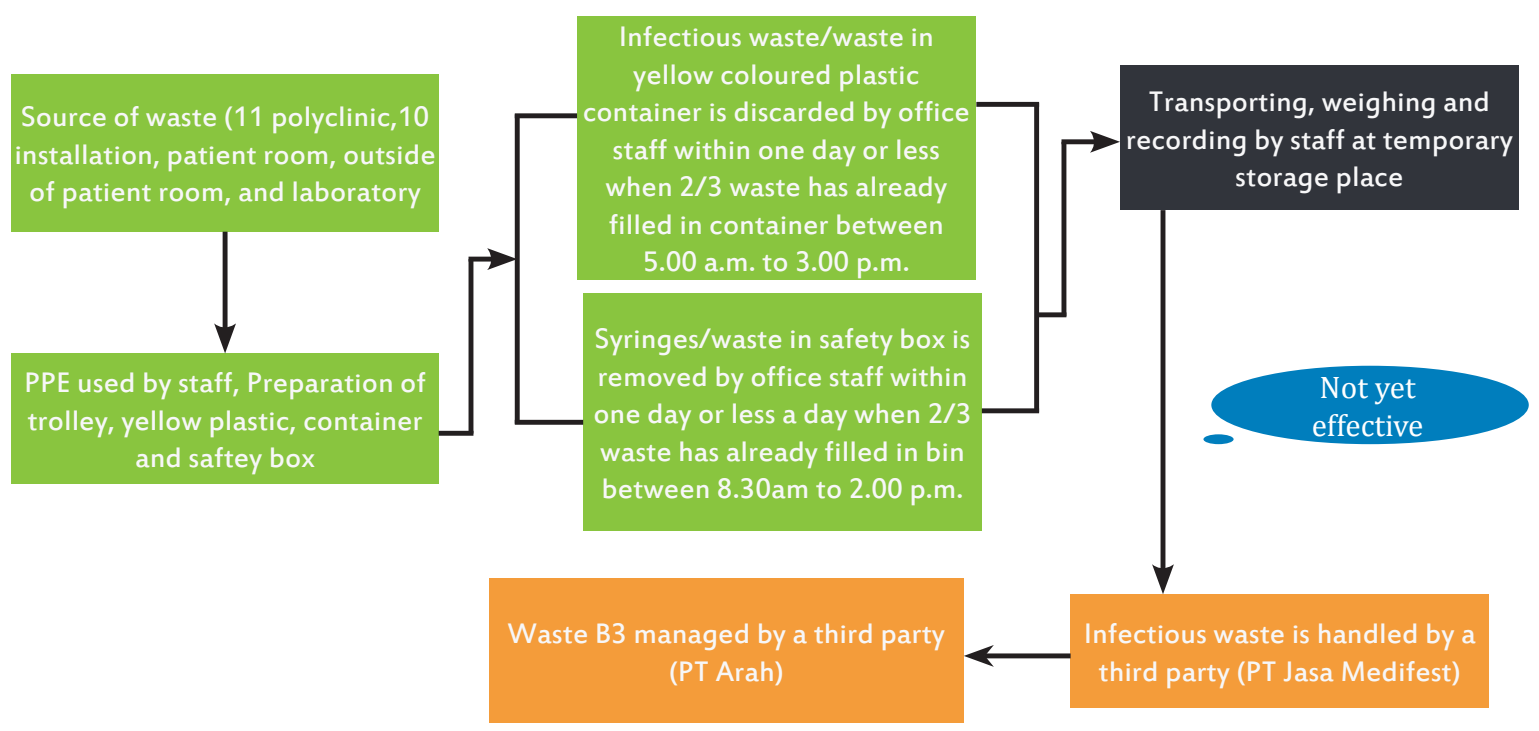

Figure 3 Process of medical derived solid waste management undertaken by the waste management staff at the RS PKU Muhammadiyah Jogja

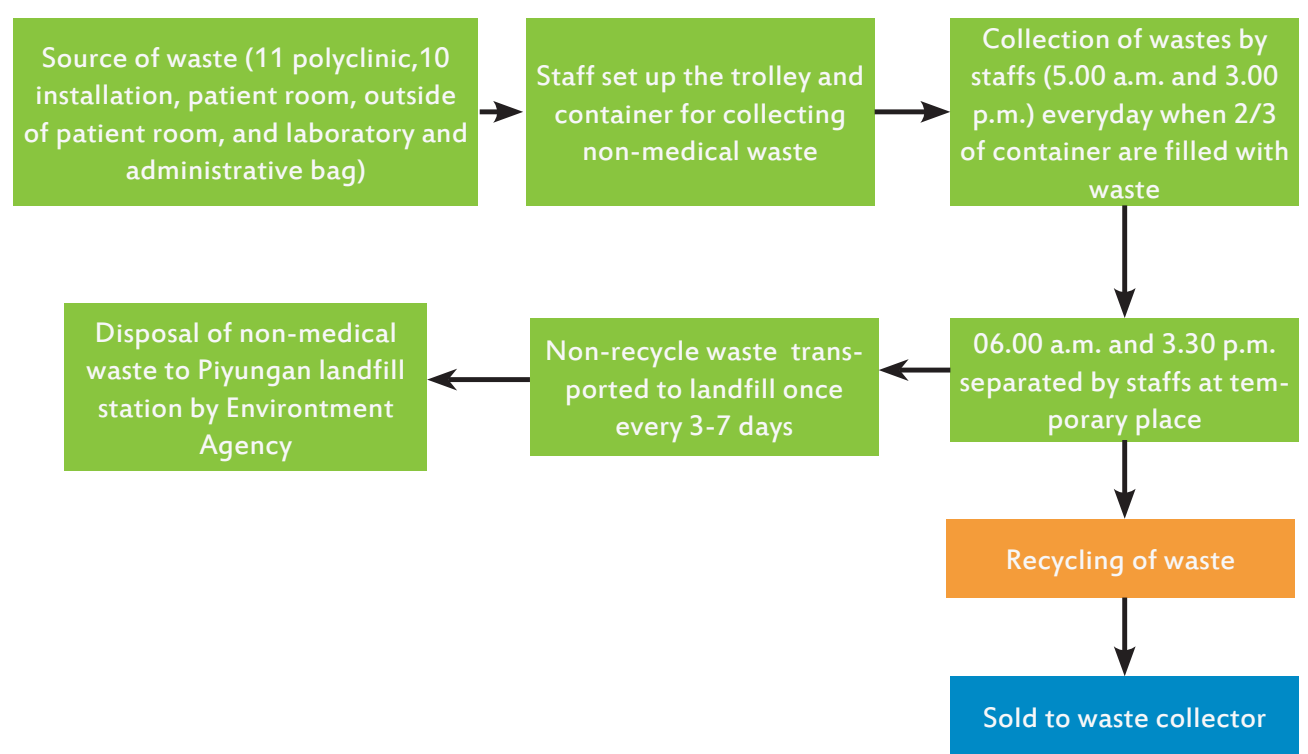

Figure 4 Non-medical solid waste treatment process by WMS conducted at the RS PKU Muhammadiyah Jogja.

2) PKU hospital in Yogya city

i. Medical solid waste processing

Figure 3 shows the medical solid waste treatment process by WMSs conducted at the RS PKU Muhammadiyah Jogja .

ii. Processing of non- medical solid waste

Figure 4 illustrates the steps of non-medical solid waste processing by WMSs conducted at the RS PKU Muhammadiyah Jogja .

\section{DISCUSSION Waste Management}

a. Jogja hospital

1). Medical waste management in Jogja hospital

The treatment process of medical waste is described based on observation and interview with waste management officer in below: 
At 8:00 a.m and 1:30 p.m., waste management staffs (WMS) prepare personal protective equipment (PPE), ranging from hats, two layer masks, gloves, aprons, shirts and special pants, boots, and also set up yellow plastic for solid medical waste, and safety box for syringe waste which is inserted in a closed trolley. Furthermore, they wear PPE and prepare closed rectangular cart for transporting medical solid waste. The next task starts at 8.30 a.m. and 2.00 p.m., the transportation of solid medical waste originating from the 11 polyclinics, 10 installation, patient, non-patient and laboratory consisting of infectious , pathological, sharp objects, pharmaceutical and cytotoxic waste of Jogja hospital. Places of solid medical waste are separated from non-medical solid waste.

A sheet of yellow colored plastic container was given at the place of putting solid medical waste with a logo and writing infectious or infectious waste. Infectious solid, pathological, cytotoxic, pharmaceuticals and chemicals waste are dumped into the yellow coated trash or place where writing medical waste or infectious waste. Plastic bags are discarded every day or less than a day when $2 / 3$ waste has already filled in container. The yellow plastic bag is tied and then inserted into a closed transport trolley. Syringes are inserted into the yellow box, which directs the transition process at the time of taking waste by WMSs and replaced with a new safety box.

Sharps objects (needles) are accommodated in a special place called safety box which is not directly placed in the room but put in bins. Thus dumping place for syringes becomes two layers. The researchers conclude that this method is effective because the waste management staffs minimize or avoid accidents during handling syringes.

After transporting all medical solid waste then these are taken to a temporary place (TP) to do weighing and recording the amount of medical waste generated during one day of transportation. Sometimes waste management staffs do not use PPE, despite the fact that the monitoring process is carried out by WMSs.
The next process is extermination where one by one parcel of medical solid waste is exposed to combustion system. Eradication is executed by burning through the incinerator with temperatures ranging from $600^{\circ} \mathrm{C}$ $800^{\circ} \mathrm{C}$ conducted by the incinerator operator. Combustion is performed approximately six hours. During extermination process, incinerator operators supervise the combustion process in a room that is adjoined directly to the incinerator. This treatment is intended to make it easier to flip through the waste that is burned to produce complete combustion and if there is any damage in the incinerator, it can be readily addressed by technician.

After completing the transportation and weighing of medical waste by WMS, trolleys are washed using water, disinfectant and detergent 3 times a day. Having finished all the process of transporting and cleaning of trolleys/box, the officer takes a shower, using soap that is provided by the Installation Environmental Health Hospital Yogyakarta. The process of cleaning during the bath by WMS intends to minimize workplace accidents or occupational diseases after taking medical waste. Residual products of combustion of solid medical waste in the form of ash are allowed to remain in the incinerator. After collecting the ash residue from the incinerator, these are dumped into the sewage sludge container of Jogja hospital. Researchers draw the interesting conclusion that the WMSs follow the guideline such as taking bath after transporting solid medical waste. Description of solid medical waste treatment process at Jogja hospital is almost equal to the study6, that is the separation and waste reduction are similar, and reduction of waste volume is an important security requirement for garbage dumping staffs. It means containers of infectious waste must satisfy the setting requirement, as well as hygiene. Research ${ }^{7}$ in five hospital found that the practiced nurses in hospital were registered in these facilities under constant surveillance and punishment with the procurement of fines, if any disposable plastic or sharp objects had found in the yellow bag, they were forced to back for 
checking waste because it can lead to injuries to health care workers.

2). Processing of non-medical solid waste: Treatment of non-medical solid waste is explained based on observations at the jogja hospital as follows:

Management of non-medical waste is performed every day routine wise by cleaning the environment inside and outside the room or building. Collecting process is executed by placing bins at strategic places and it is easily accessible for visitors and cleaning staffs both inside and outside the building. Non-medical pile of garbage are managed by the system or direct communal pattern that is collecting the waste in the bin is taken to be cleaned every two times a day.

Activities by WMSs are conducted between 8:00 a.m. and 01:30 p.m. To begin the process of transporting solid waste, waste management staffs prepare large trash tub four in total in order to accommodate the huge amount of solid waste, move trash tub using a trolley for easy to reach dumping places for non-medical trash throughout the Jogja hospital. Waste management staffs collect non-medical solid waste sources from several places, namely, 11 polyclinics, 10 installation, inside patient room, outside patient room, laboratory and administrative section.

Having collected non-medical wastes then these are separated into recyclable and nonrecyclable wastes at different bins respectively. Researchers conclude that this treatment is effective because it accelerates the process of making non-medical waste to the polls, so that WMSs are not glued with recycle and non- recycle wastes at the Yogyakarta hospital. The process of transporting non-medical solid waste begins on the second floor and then the first floor. Besides, the trashes are collected if any other wastes are scattered in the hallway or in the ward of hospital. In later these collecting wastes are taken into polling station and divided into recyclable and nonrecyclable garbage by WMSs. Non- recyclable wastes are kept in special place of dumping station, which will be brought to Piyungan dumping station later.

While recycle wastes are also put at specific place of dumping station. On certain days transaction occurs between staffs and garbage collectors. Having sorted out and discharged garbages, the trash tubs are cleaned near waste incinerator.

Disposal of non-recycled is executed with regional health office in Yogyakarta to be brought into landfill waste station. The frequency of the transportation is twice a week, but sometimes once a week.

The Places of hospital where waste is stored before being taken to the final disposal site is termed as temporary storage of waste. This area should be cleaned and secured in such a way that it can only be accessed by authorized persons. ${ }^{8}$ When its two-thirds are filled then primary waste containers are sealed and taken to permanent dumping place. In most hospitals, bulk garbage carts are used to facilitate the collection of waste from the clinical area, and for temporary storage of waste until the carriage taken by the contractor for final disposal. ${ }^{9}$

During handling and separation of non-medical wastes such as waste paper, plastic and glass WMSs use their own gloves so that any infectious thing cannot transmit due to the use of gloves of another staff.

b. RS PKU Muhammadiyah Jogja

1) Management of medical waste

Treatment process of solid medical waste at the RS PKU Muhammadiyah Jogja begins with pick up trash from the polyclinic, installation, patient room, outside patient room, and laboratory. Different sorts of wastes such as Infectious solid, pathological, cytotoxic, pharmaceuticals and chemicals waste are collected. Then an isolation room solid medical wastes are separated from non-medical solid waste. A layer of yellow colored plastic container is provided at the place of keeping solid medical waste with a logo and writing infectious or infectious waste so that these are dumped into the yellow coated trash or place where writing medical waste or infectious waste. Plastic bags are discarded every day or 
less than a day when $2 / 3$ waste has already filled. The yellow plastic bag is tied and then inserted into a closed transport trolley. Syringes are inserted into the yellow box, which directs the transition process at the time of taking waste by WMS and replaced with a new safety box.

Sharps objects (needles) are accommodated in a special place called safety box which is not directly placed in the room but put in bins. Thus dumping place for syringes becomes two layers. The researchers conclude that this method is effective because the waste management staffs minimize or avoid accidents during handling syringe.

After transporting all medical solid waste then these are taken to a temporary place (TP) to do weighing and recording the amount of medical waste generated during one day of transportation. Sometimes waste management staffs do not use PPE, despite the fact that the monitoring process is carried out by WMS.

The next process is destruction of collected wastes by burning, which is carried out by a third party (PT Direction) for hazardous materials and toxic waste (B3) and by PT Jasa Medivest for infectious waste. This treatment is carried out outside PKU hospital as it is located in the city center and settlements, so it is not possible to perform combustion using incinerator. Incinerators are designed to have burnt waste by leaving the residue in the form of ash and must be fitted with a scrubber to trap released toxic pollutants. ${ }^{10}$ Disposal wastes such as stored chemicals, disinfection, steam autoclaves and imperfectly burned without pretreatment may contain potentially harmful microorganisms. ${ }^{11}$

Based on research findings it can be concluded that the treatment process of solid medical wastes at RS PKU Muhammadiyah Jogja needs to be improved and perfected. Combustion process of infectious wastes is carried out by a third party named PT Jasa Medivest while B3 is executed by a third party, named PT Arah. This is because RS PKU Muhammadiyah Jogja does not have incinerator due to its position where the residents of civil people and office complex are located, so it will be disturbed if the burning or destruction is carried out.

\section{2). Management of non - medical waste}

Management of non-medical waste is performed every day routine wise by cleaning the environment inside and outside the room or building. Collecting process is executed by placing bins at strategic places and it is easily accessible for visitors and cleaning staffs both inside and outside the building. Non-medical garbage is managed by the system or direct communal pattern that is collecting the waste in the bin is taken to be cleaned every two times a day, namely at 5.00 a.m. and 3.00 p.m. is almost the same as the retrieval of medical solid waste.

The first task for WMSs is to prepare the trolley and tub for taking non-medical waste. Having collected non-medical wastes then these are separated into recyclable and nonrecyclable garbage at different container respectively. Subsequently Recycle and nonrecycle wastes are kept at temporary shelter place, however later many pile of non-recycle garbage are brought to the landfill waste station in Bantul. Research at the Thammasat hospital concluded that the best solutions for waste disposal are sanitary landfill and incineration concur with the adaptation of technology. ${ }^{11}$

Treatment process of recycling waste at the RS PKU Muhammadiyah Jogja is almost equal to the study ${ }^{12}$, that is the waste collection and transportation workers in the Hospital separate recyclable waste for sale. In the same way, all disposable plastic items are separated by WMSs, where garbage is stored in the hospital courtyard, or outside in the hospital community for further transportation and disposal along with municipal solid waste.

\section{Effectiveness of solid waste treatment}

Based on the above explanation it can be reported that each hospital already has a clear pathway for waste treatment. Waste treatment in hospital Jogja is groove-planned and effective with reference to the Decision 
of the minister of health No. 1204/Menkes/ SK/X/2004 about environmental health requirements at hospital, shown with implementation guidelines and technical guidance of waste treatment, while RS PKU Muhammadiyah Jogja already has clear Standard operating procedure (SOP) but yet does not have the proper implementation and technical guidance. ${ }^{13}$ Weak management of clinical waste exacerbates the risk of infection for those medical wastes are exposed. The cleanliness of hospital has implication on infection control. ${ }^{14}$ The distinction between public and private hospital is mainly the size of the unit or section in hospital. In general hospital there are several parts such as installation plant which is responsible for garbage collection, transport place temporary storage facility, off-site transportation and final disposal. While at the private hospital, cleaning service do all waste management operations in hospital before off-site transportation is done by the company responsible for final disposal.

\section{CONCLUSION}

This study shows a case of solid waste management in hospital. The results showed the following evidences:

1. RS Jogja and RS PKU Muhammadiyah Jogja already have a clear Standard Operating Procedure (SOP), however RS Jogja has more clearer SOP, implementation and technical guideline.

2. Treatment processing of solid medical waste at the RS PKU Muhammadiyah Jogja less effective compared to RS Jogja as they do not have own incinerator and execute the combustion process of infectious waste by a third party (PT Jasa Medivest), as well as the B3 waste by a third party (PT Arah) while RS Jogja already has a medical waste incinerator to burn directly.

3. Waste treatment in hospital Jogja is followed by well-planned and effective guideline with reference to the Decree of the Minister of Health No.1204/Menkes/SK/X/2004 about Environmental Health Requirements in Hospital, shown by implementation guidelines and technical instructions in waste treatment, while yet PKU hospital in Yogyakarta city does not have the proper implementation and technical guideline.

\section{SUGGESTIONS}

The suggestions of this study are:

1. The management and environmental sanitation installation section in Jogja hospital should provide guideline and training based on the latest science of waste treatment, so that the workers can understand and know in depth on waste treatment.

2. To improve and cooperate of the waste treatment process specially final process of medical solid waste in RS PKU Muhammadiyah Jogja should work with PKU Gamping that can streamline costs due to the persistence of the foundation.

\section{REFERENCES}

1. Health department Number:1204/MENKES/SK/X/2004.Environmental health requirements in hospital. Jakarta: DG, PPM \& PL, Ministry of health, Republic of Indonesia; 2004.

2. Adisasmito. Audit on hospital environment. Jakarta: Raja Grapindo Persada; 2008.

3. WHO. Safe health care waste management,First edition. Jakarta: EGC; 2005.

4. Joglosemar. $64 \%$ Special waste management in hospital. Wednesday, 18/11/2009. <http://joglosemar.co.id/joglosemarcetak/2009/IPTEK/index.html>, accesed may 2010.

5. Notoatmodjo S. Research Metodology of health, third edition, Jakarta: PT Rineka Cipta; 2005.

6. Alamsyah B. Waste management at the $\mathrm{Pu}$ puk Kaltim Bontang hospital to meet the Standard Environmental Quality (Thesis). Semarang: UNDIP; 2007.

7. Rao LCS. Ranyal WCR. Bhatia LCS \& Sharma LCV .Biomedical Waste Management:An Infrastructural Survey of Hospitals. Contemporary Issue. MJAFI 2004; 60 : 379-82.

8. Askarian M, Vakili M \& Kabir G. Result of Hospital Waste Survey in Private Hospitals in Fars Province, Iran. Journal of Waste Management 2003; 24: 347-52.

9. Blenkharn JI. A Potential compromise of hospital hygiene by clinical waste carts. J Hosp Infect 2006; 63: 423-7. 
10. Ali G, Nitivattananon V, Molla NA \& Hussain A. Waste Management: A Case of Thammasat Hospital, Thailand. World Academy of Science, Engineering and Technology 2010; 64.

11. Phengxay S, Okumura J, Miyoshi M, Sakisaka K \& Kuroiwa C. Health-care waste management in Lao PDR: a case study. Waste Manag Res 2005; 23: 571-81.

12. Radha KV, Kalaivani K Lavanya R. A Case Study of Biomedical Waste Management in Hospitals. Glob J Health sci 2009;1 (1):82-8.

13. Blenkharn JI. Standards of clinical waste management in UK hospitals. J Hosp Infect 2006; 62:300-3.

14. Ferreira V \& Teixeira MR. The Medical Waste Management Practices and Associated Risk Perceptions in Algarve Hospitals, Portugal. Portugal: Faculty of Sciences and Technology, University of Algarve, Campus de Gambelas, Faro; 2010. 